\title{
A causal relationship model of factors affecting competitiveness of community enterprise in the central region
}

\author{
Pinyapat Nakpibal $^{1}$, Laiad Kajonpai $^{2}$, Pitchayanee Choengkeeree Chaiya ${ }^{3}$, Pornpen Traiphong ${ }^{4}$ \\ ${ }^{1,2}$ Faculty of Management Sciences, \\ ${ }^{3}$ Faculty of Humanities \&Social Sciences, \\ 1,2,3 Valaya Alongkorn Rajahat University under the Royal Patronage \\ ${ }^{4}$ Suan Dusit University \\ 1boon25552555@gmail.com,2 laiad@ vru.ac.th, ${ }^{3}$ Pitchayaneecc @ gmail.com, ${ }^{4}$ cherrypornpen@yahoo.com
}

\begin{abstract}
The purpose of this research were 1) to investigate the competitiveness of community enterprise, 2) to measure an agreement, and 3) to find a structural model of knowledge management, transformational leadership, and human capital development affected to community enterprise's competitiveness. Multiphase mixed methods research applying quantitative research to extend qualitative results was used for research design. The qualitative target group was selected using purposive sampling whereas the quantitative sampling group was used two-stage random sampling. Questionnaires were used for measurement design. Qualitative data were classified and analyzed using content analysis and analytic induction. Quantitative data were analyzed by descriptive statistics and the developed model was validated by using LISREL program. The research found that 1) the overall competitiveness of community enterprise was in a high level. The interview result shown that the transformational leadership adopted the Sufficient Economy philosophy of "to do one thing at a time", encouraged members to have a positive attitude of sharing idea. The leader should seeking for new knowledge and sharing benefits equally, applying local resources and wisdom to human capital making product development such as chili paste from mushroom, herbal product, etc. 2) The competitiveness of community enterprise's empirical data had statistical agreement $x^{\wedge} 2=339.19, \mathrm{df}=90, \mathrm{P}-\mathrm{value}=.00$, most index were close to .90 . The interview result found the successful of business came from product differentiate strategy. The product must be unique and stand out from competitors such as herbal compress, ikat silk, snack from rice, etc. There was also a cost leadership strategy be used. 3) The competitiveness of community enterprise was directly influenced by 3 factors; knowledge management (Direct Effect or DE=.26) transformational leadership (DE=.39) and human capital development ( $\mathrm{DE}=.34)$ whereas indirect effects came from a transformational leadership by knowledge management (Indirect Effect or IE=.89) and human capital development ( $\mathrm{IE}=.76)$. Therefor the model developed was acceptable and good to be used for forecast the competitiveness of community enterprise in the central region. The form of the 3 factors that affect to the competitiveness was $3 \mathrm{~L}$ Model for SMEs Competitiveness based on the developing of members' abilities; supported knowledge, upgraded skill, etc. The head of community enterprise must emphasized on mission and goal setting, kindness, participation of members, motivation, employing competitive advantages of product differentiate, niche marketing, and cost leadership.
\end{abstract}

Keywords

Community Enterprise, Competitiveness

Article Received: 10 August 2020, Revised: 25 October 2020, Accepted: 18 November 2020

\section{Introduction}

A community enterprise is a community about the production of products, provision of services, or other activities performed by a group of people within the relationship that have a common way of life and come together to operate such businesses to generate income and self-reliance of family, community, and between communities. Community enterprise has benefits for a society which leads to the development of high-quality human capital, generate income for the community, the communities are strong, able to rely on themselves, improving the quality of life of the people, and develop the economic growth of the country.[1]

Community enterprise promotes innovations, creating careers and jobs, encouraging consumption, as well as causing circulation in the country's financial system, consistent with the policy of the World Trade Organization, and support community-level entrepreneurship in setting up a business.[2] It was found that the operating problems of community enterprise in the central region include management, marketing, and production. To achieve the competitiveness of community enterprise, the central region should have components such as leadership, knowledge management, and the development of human capital of community enterprise.[3]

Community enterprise is the community that deals with product production, service provision, human capital development, leadership, knowledge management, and community creation to raise the quality of life of the people and supporting the economic development of the country forwards. This is why the research team is interested in studying the causal relationship pattern of factors affecting the competitiveness of community enterprise in the central region to develop leadership, knowledge management, and human capital development that can create a competitive advantage for community enterprise.

\section{Research Objectives}

The objectives of this research article were 1) to study factors of transformational leadership, knowledge management, and human capital development affecting the competitiveness of community enterprise in the central region. 2) to test for consistency of transformational 
leadership, the change of knowledge management, and human capital development affecting the competitiveness of community enterprise in the central region.,.and3) to find a pattern of transformational leadership, knowledge management, and human capital development affecting the competitiveness of community enterprise in the central region.

\section{Research Methods}

\section{A. Research design}

Action research and quantitative research were used and research tools were interview form and questionnaires. Data were collected from in-depth interview, focus group discussion and quasi-experimental design. Qualitative data from 30 key informants was analyzed by using content analysis whereas quantitative data collected from [4] 320 samples was analyzed by using descriptive statistics.

The researcher scope (a) Content scope of transformational leadership, knowledge management, human capital development, and competitiveness. (b) The scope of variables used in the research consisted of 1) the primary variables are transformational leadership, knowledge management, and human capital development, and2) the dependent variable is competitiveness. (c) The scope of the area is community enterprise in the central region. (d) Population and samples scope.1) Population is customer and 2) Sample using the formula of Hair and others, [5] 20 times per parameter or number of paths equal to 16 paths, the sample was 320 .

2.Sampling method using proportional to size by systematic sampling, selecting samples according to the location of the central region community enterprise includes Pathum Thani, Phra Nakhon Si Ayutthaya, Ang Thong, Singburi, Saraburi, and Lopburi [6]

3. Tools including interviews and questionnaires are divided into 5 parts: personal factors, knowledge management, transformational leadership, human capital development, and competitiveness of community enterprise.

4.Statistic includes frequency, percentage, mean, standard deviation, skewness, kurtosis, factor analysis for EFA, confidence, accuracy, and statistical package, finding the confirmation factor analysis (CFA) and test the hypothesis using Structural Equation Modeling (SEM) analysis to obtain Path Analysis. [7]

5. The qualitative data analysis was done by using content analysis and triangulation method from informants involved in knowledge management, transformational leadership, human capital development, and competitiveness for research in social with the use of the statistical package.

The process of implementation were consisted of 1) documentary study from primary sources including customer

and the secondary sources include scripture commentary, research books, articles and other related documents, 2) an area study of community enterprise in the central region.

understanding community enterprise group and stakeholders about the purpose of the operation and the target, 3) community enterprise volunteers who are the target audience and subscribe, 4) participants meeting in the community to find problems and the need to solve the problem together, 6) preparing materials, 7) doing, and 8) data processing at every stage of the compilation, analysis and presentation summarizing the findings.

\section{B. Research Process}

Research process of this research has developed into 4 steps were shown in Fig. 1.

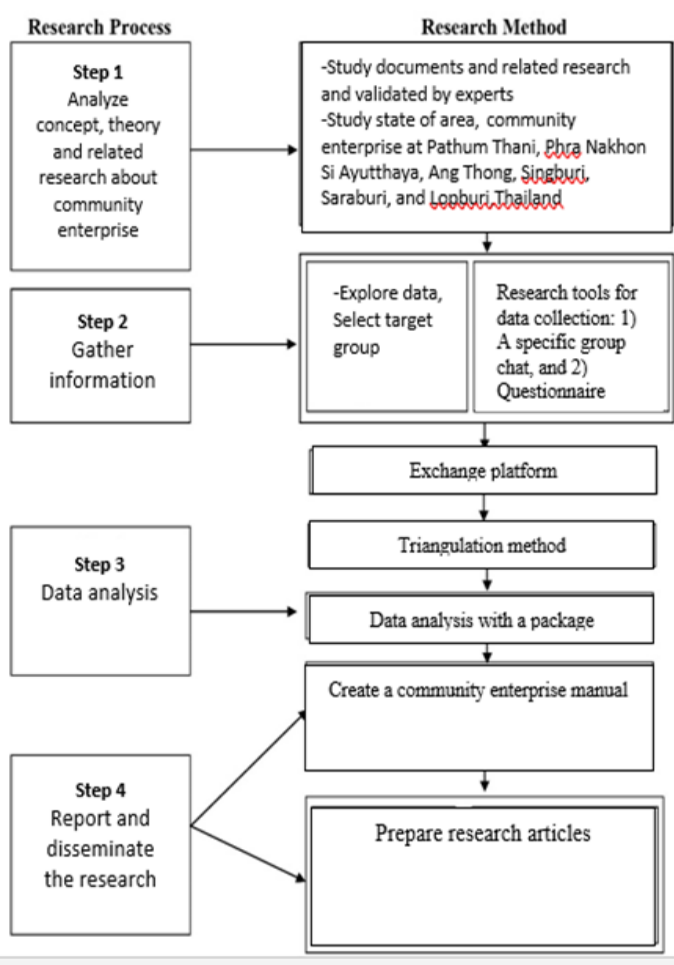

Fig.1 Research process for a causal relationship model of factors affecting competitiveness of community enterprise in the central region

\section{B. Research Process}




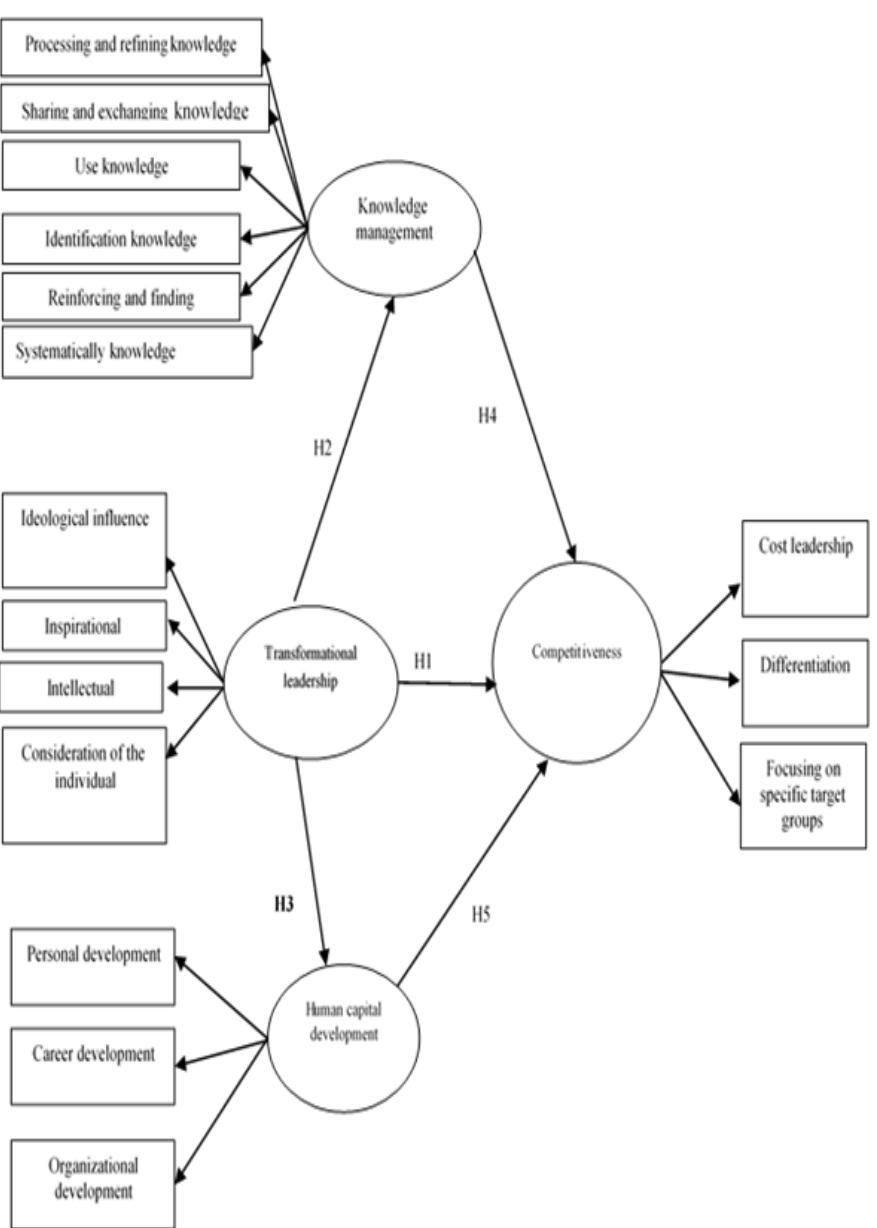

Fig.2 A causal relationship model of factors affecting competitiveness of community enterprise in the central region

\section{Realated Literature}

The competitiveness of community enterprises is driven by cost leadership, utilizing the ability to manage the business from upstream to downstream to have the most suitable low cost, differentiation by inventing a unique product design and better quality, and focus on the niche market based on.[8].[9].[10]. It was found that there are factors that support competitiveness, including :Transformational leadership consists of ideological influence, inspiration, intellectual stimulation and consideration of the individual, and sharing knowledge in the organization.[11].[12]. Knowledge management consists of the Office of the Public Sector Development Commission and human capital development consists of.[13].[14]

The conceptual framework has studied the background of the potential and problems of the enterprise. After that the customers' opinions were then surveyed about factors influencing the competitiveness of community enterprise, human capital development, transformational leadership, and knowledge management of community enterprise, which is consistent with the research hypothesis as follows:

1.Leadership variables have direct influence on the competitiveness of community enterprise.
2.Transformational leadership variables directly influence the competitiveness of community enterprises through the variables passed on knowledge management.

3.Transformational leadership variables directly influence the competitiveness of community enterprises through variables passed on human capital development.

4.Knowledge management variables directly influence the competitiveness of community enterprises.

5.Human capital development variables directly influence the competitiveness of community enterprises.

\section{Results}

Results indicated that 1) assessing the potential of community enterprises in the central region with an assessment form and situation analysis, it was found that the leaders of community enterprise management, market management, and knowledge management in overall is good, representing 78.17 percent. When considering the results of the assessment of the provincial potential in descending order, it was found that the results of the assessment of the highest potential were community enterprise of Ang Thong Province, representing 88.00 percent, followed by community enterprise in Saraburi Province, representing for 84.50 percent and the least is the community enterprise in Phra Nakhon Si Ayutthaya Province, representing 66.10 percent.

2)Strengths of community enterprises contains high quality and safe ingredients such as cultivated banana, Bhutan oyster mushroom, Jekchoy rice, etc. Products that are processed from herbs, Bhutan oyster mushroom, banana, fish, and loincloth, etc. Community products are certified by the Food and Drug Administration (FDA), Good Manufacturing Practice (GMP) standards, and Geographical Indication (GI) and community product distribution locations such as community markets, malls, Future Park Rangsit, and Zeer Rangsit. Government sectors such as Valaya Alongkorn Rajabhat University under the Royal Patronage and district and provincial government centers.

3)Weaknesses of community enterprises are some groups have insufficient raw materials for production or insufficient equipment such as fish grinder, fish scaling machine, flour production machine, etc. Place or house lacking standard and banana processing technique are not up to standard. Sometimes the processing of a product does not meet customer requirements such as cloth bags and delays in delivery.

4)Community enterprise opportunities, locations of most community enterprises come with convenient transportation that promotes unity and the income of the group. It also is a learning center for the sufficiency economy and agricultural and fish products processing. Customers have confidence in the reputation of products such as Mae La Dried Fish. Along with government sectors give support and promote the implementation of knowledge and budgets.

5)Threats of community enterprises, they face the weather like continuous rain, mushroom cubes formed a fungus, high price of mushroom cubes, delayed ordering of raw materials, many competitors, and packaging and branding are not up to standard and not interesting. In addition, most community products lack standard certification. 
6)Competitiveness of community enterprises in the central region, overall is at a high level. When considering the factors affecting the competitiveness of community enterprises in descending order, it was found that the side with the highest average was transformational leadership of community enterprise, followed by community enterprise knowledge management, and human capital development, which the respondents had no different opinions and little information is distributed

7)Testing for the consistency of variables of transformational leadership of community enterprises, knowledge management of community enterprises, and human capital development affecting the competitiveness of community enterprises in the central region are as follows: (1) The analysis results of three variables were divided into Factor 1, namely transformational leadership of community enterprises, with 8 variables, $69.157 \%$ variance, and high confidence. Factor 2 was the knowledge management of community enterprises with 6 variables, $59.038 \%$ variance, and moderate confidence. Factor 3 was the human capital development of community enterprises with 2 variables, $30.146 \%$ variance, and confidence. (2)Model of the competitiveness of community enterprises is consistent with the empirical data because the variable weight is greater than .04 , the chi-square (x2) is equal to 339.189 , the degree of freedom (df) is 90 , the probability (p) is .00 , and the index is close to 90 . In the structural model influence, the model path was found that the latent variables of the knowledge management factor of community enterprises have a direct influence on the latent factor variables. The competitiveness of community enterprises is equal to .26. The latent variables in transformational leadership of community enterprises have a direct influence on the latent variables on the competitiveness of the community enterprise equal to .39. Human capital development variables of community enterprises have a direct influence on the latent factor variables on the competitiveness of the community enterprise equal to .34 . The latent variables of transformational leadership of community enterprises indirectly influence the competitiveness of the community enterprise through the knowledge management variables of the community enterprise and the human capital development of community enterprises. Therefore, the developed model has good and acceptable predictability of the competitiveness of community enterprises in the central region, as well as the analysis results supporting the research hypothesis.

8. Patterns of transformational leadership, knowledge management, and human capital development affecting the competitiveness of community enterprises is $3 \mathrm{~L}$ Model SMEs for Competitiveness. The operation of community enterprises takes into account the development of members' potential, support and promote knowledge and skills, organize a learning system. The chairman of the community enterprise has an attribute of kindness, raising awareness of members, alluring on works, members understand the goals and missions of the group. It also creates strategies to support competitiveness, including cost leadership, differentiation, and focusing on a niche market.

\section{Discussions}

1. Comment level on transformational leadership, knowledge management, and the human capital development of community enterprises. It was found that respondents regarding transformational leadership were at a high level, in which leaders inspire, build up relationships, and cooperative work. It is consistent with the concept of [15] mentioned about the fundamentals of transformational leaders: inspiring subordinates to strive for action and in line with the research of [16] found that the administrators of Phato Sub-district administrative organization, Chumphon province were at a high level. Caused by the management to create awareness and motivation of the co-workers. The knowledge management, it was found that the respondents had opinions about knowledge management at a high level. The community enterprise group has recorded the successful work of personnel to create a systematic database and then use the information to work and solve problems. It is consistent with the concept of [17] mentioned about collecting data into categories and then show the results of the user needs and consistent with the research results of [18] It was found that personnel of the Tambon Administrative organization Laem Sing district, Chanthaburi province. There was a high level of opinion about knowledge management systematically. Along with the development of human capital, it was found that the respondents were a high level of opinion about human capital development. The chairman supports and promotes new knowledge and skills to members. It is consistent with the research of [19] found that academic personnel in Suratthani Rajabhat University. There are opinions about human capital development at a high level.

2. Factors affecting the competitiveness of community enterprises were found that the knowledge management of community enterprises had a direct influence on the competitiveness of the community enterprises with a value of 0.26. Transformational leadership of community enterprises has a direct influence on the competitiveness of the community enterprise is equal to 0.39 . The human capital development of community enterprises has a direct influence on the competitiveness of community enterprises with a value of 0.34 . The test results of variables of transformational leadership, knowledge management, human capital development, and the competitiveness of community enterprises are consistent with the empirical data within acceptable criteria, the chi-square $(x 2)=339.189$, the degrees of freedom $(\mathrm{df})=90$, the probability $(\mathrm{p})=.00$, and most of the indices are close to .90 . The results of hypothesis testing showed that transformational leadership, knowledge management, and human capital development have direct influences on the competitiveness of community enterprises. Transformational leadership has an indirect influence on the competitiveness of community enterprises at the statistical significance level of .01, consistent with the concept of [20]mentioned the characteristics of leaders affect the operational ability of the organization and consistent with the research of[21] found that transformational leadership includes ideological influence, inspiration, intellectual stimulation, and a positive influence on the performance of the organization. Knowledge management is consistent with the concept of [22] the 
learning of personnel, able to adapt to changing situations, and creates more potential and competitive advantages. It is consistent with the research results of [23] found that knowledge management to community organizations in selfreliance sustainable, by making a career in agriculture. Management of savings group for production and transfer of experience, make the community organization recognized and the trust of the people along with the human capital development and consistent with the research of [24] found that the human capital potential of entrepreneurs in the Thai software industry has a positive direct influence to compete.

4. Patterns of transformational leadership, knowledge management, and human capital development affecting the competitiveness of community enterprises.

From the research results, information synthesis was obtained. Patterns of transformational leadership, knowledge management, and human capital development that affect the competitiveness of community enterprises are $3 \mathrm{~L}$ Model SMEs for Competitiveness shown in figure Fig.3

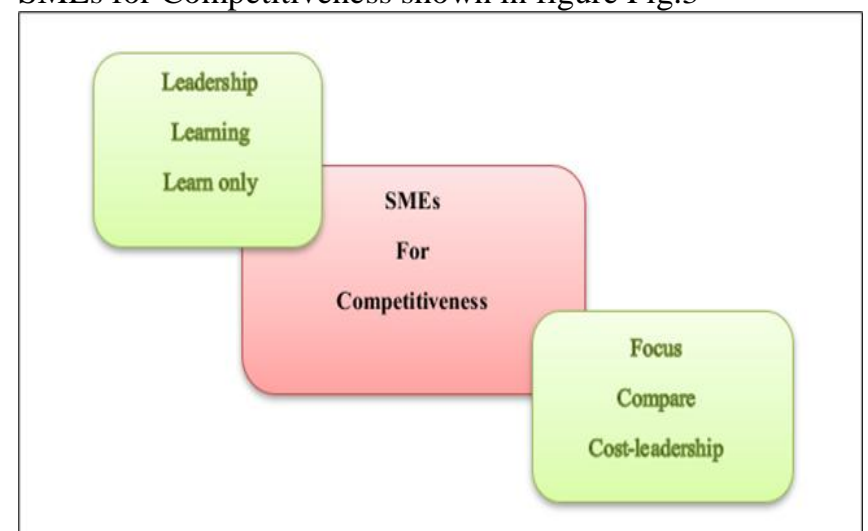

Figure3: Patterns of transformational leadership, knowledge management, and human capital development affecting the competitiveness of community enterprises.

From figure 3, it was found that community enterprises with competitiveness, strategies are set including 1) cost leadership (Cost-leadership: C) that producing products or services at low cost. Ready to present products and services that are lower than competitors in the market. 2) Compare (Compare: C) competitors to find the difference in the products or services, makes it stand out from the competition and 3) focus (Focus: F) on niche marketing to reach customer behavior. Resulting in repeated purchases of products or services and be loyal. In addition, human resources are important to drive community enterprises over competitors by thinking of transformational leadership (Leadership: L). The chairman of the community enterprise has an attribute of kindness, raising awareness of members, alluring on works, members understand the goals and missions of the group. 2) Gathering knowledge from members (Learning: L) with work notes to keep data systematic and all members have easy access to knowledge and 3) supporting and promoting members to perform their duties efficiently.

Therefore, the pattern of transformational leadership, knowledge management, and human capital development affecting the competitiveness of community enterprises. The competitiveness of community enterprises (SMEs for Competitiveness: FCC) consistent with [25] mentioned competitive strategies including cost-leadership, differentiation, and focus factors that support and promote the operation of community enterprises are as follows: 1) Leadership: L, consistent with the concept of [26] mentioned to the fundamentals of community enterprise leaders. 2) Collecting knowledge from members (Learning: L) consistent with the [27] mentioned the concept of gathering and utilizing information and 3) support and promote members of knowledge and skills (Learn only: L) consistent with the 12th socio-economic development plan, strategic issue 1 , the modification of desirable behavior of the country, develop potential knowledge and skills to live a life with value.

\section{Recommendations}

\section{A. Recommendations for Practices}

1. Discover the privatized community enterprises and food products registered as a community enterprise for less than 5 years, there is an insufficient number of the equipment for the production such as fish grinders, flour production machines, etc., product processing is inconsistent with customer demand, the climate affects to the quality of production, and most community products lack standard certification. Therefore, a network of community enterprises in the central region should be created to achieve the exchange of knowledge, local wisdom, apply knowledge and use it properly, and there are public relations and publicizing products of community in a wide area.

2. Discovered that community enterprises that have recorded operating data to increase competitiveness should create a systematic database by technology.

3. Discovered how transformational leadership has a direct influence on the competitiveness of community enterprises should focus on inspiring cultivating awareness among members who focus on cooperative work target communication and mission to members to stimulate the operation of community enterprises to be efficient.

4. Discovered that the development of human capital has a direct influence on the competitiveness of community enterprises from asking community enterprises. Therefore, the group's chairman should be promoted to new knowledge and skills for effective work.

5. Related government sectors able to bring knowledge from research lead to planning the development of community enterprises in Thailand.

\section{B. Recommendations for Further Research}

1. Should study the network of community enterprise groups, Handicraft group Herbal products, woven fabrics, etc., in order to get the Nawatwithi Community Enterprise Network to support the ASEAN Community

2. Should study the development of community enterprises according to the principle of Nawatwithi Is bringing local wisdom. The way of life in the production of local products under the concept of co-happiness, contemporary ways, together with the integration of community tourism.

3. They should study knowledge management of upstream, midstream, and downstream community enterprises and disseminate them to social media. 
4. Should study human capital development, community enterprises in the dimension of skills development Learning development and attitude development Creating a social capital, trusting cooperation towards the development of community enterprise groups

\section{Conclusion}

In conclusion, the findings from the analysis of both quantitative and qualitative showed that a causal relationship model of factors affecting competitiveness of community enterprise in the central region. The research found that 1) the overall competitiveness of community enterprise was in a high level. 2) The competitiveness of community enterprise's empirical data had statistical agreement $\mathrm{x} 2=339.19, \mathrm{df}=90, \mathrm{P}$-value $=.00$, most index were close to .90 . 3) The competitiveness of community enterprise was directly influenced by 3 factors; knowledge management (Direct Effect or DE=.26) transformational leadership (DE=.39) and human capital development (DE=.34) whereas indirect effects came from a transformational leadership by knowledge management (Indirect Effect or $\mathrm{IE}=.89)$ and human capital development $(\mathrm{IE}=.76)$. Therefor the model developed was acceptable and good to be used for forecast the competitiveness of community enterprise in the central region. The form of the 3 factors that affect to the competitiveness was $3 \mathrm{~L}$ Model for SMEs Competitiveness based on the developing of members' abilities; supported knowledge, upgraded skill, etc. The head of community enterprise must emphasized on mission and goal setting, kindness, participation of members, motivation, employing competitive advantages of product differentiate, niche marketing, and cost leadership.

\section{References}

[1] Office of the National Economic and SocialDevelopment Board ,Economic and Social Development Plan,2016.

[2] World Trade Organization, "Trade Policy Review Chile", reported by the Secretariat,WT/TPR/S/124, Geneva.,2003.

[3] Department of Agricultural Extension, Overview report of the assessment of the potential of community enterprises, 2015.

[4] [5] Hair, J., et al., Multivariate data analysis (7th ed.). Upper saddle River, New Jersey:Pearson Education International,2010.

[5] [7] Kalaya Vanichbancha, Advanced Statistical Analysis with SPSS for Windows, Bangkok: Chulalongkorn University,2013.
[6] [25] Porter, M. E., Competitive strategy: Techniques for analyzing industries and competitions. New York: Free Press, 1980.

[7] Martin, R. L., \& Osberg., S. Social entrepreneurship: The case for definition. Stanford Social Innovation Review,vol.5, no.2, pp.29-39,2007.

[8] Unger, N., D.T. Shindell, and J.S. Wang,Climate forcing by the on-road transportation and power generation sectors. Atmos. Environ, vol.43, pp.30773085 ,

doi:10.1016/j.atmosenv.2009.03.021.,2009

[9] Christopher A. (2013). Transformational Leadership and Knowledge Sharing in ICT Based Organizationsin Nigeria. International Journal of Business and Social Science. vol.4, no.12, pp.100-106, 2013

[10] [21] Victor Jesus Garcia. Morales., Transformational Leadership influence on Organizational performance through organizational learning and innovation, Journal of Business Research, vol.6, no.65, pp.1040-1050,2010.

[11] Ployhart, R. E., \& Moliterno, T. P., Emergence of the human capital resource: A multilevel model. Academy of Management Review, vol.36, no.1, pp.127-150,2011.

[12] Chidi, C. O., \& Shadare. O. A., "Managing Human Capital Development in Small and Medium-Sized Enterprises for Sustainable National Development in Nigeria”,2011.

[13] [26] Bass, B.M., \& Avolio, B. J, Manual for the multifactor leadership questionnaire. Palo Alto, CA: Counseling Psychologist Press, 1996.

[14] Ashya kisalang et al, Relationship between transformational leadership of administrators and job satisfaction of school teachers. Under the municipality of Nakhon-phanom. Journal of Nakhonphanom University. vol.1, no.2, p.111, 2011.

[15] [27] Wiig, K., Knowledge Management Foundations: Thinking About thinking 
How Organizations Create, Represent and Use Knowledge. Arlington, TX: Scherma Press., 1993

[16] Chonglaksawet Thammathama, Knowledge management of the Tambon Administrative Organization, Laem Sing District Chanthaburi Province, Master of Business Administration, Thesis Business Administration, Rambhaibarni Rajabhat University,2013.

[17] Pichayada Pimsing,Factors that are Important to Human Capital Development of Academic Professionals in Surat-Thani Rajabhat University, Journal of the Graduate School of Pichayatorn, vol.10, no.1, pp. 45-54, 2015.

[18] Stogdill, R. M., Handbook of leadership. New York: The Free Press, 1974.

[19] Somchai Namprasertchai, Knowledge management. Bangkok: SEEDUCATION,2015.

[20] Prapun Nutkrathok,Social capital and knowledge management towards sustainable self-reliant community organization, In the lower northeast, Doctor of Arts Department of State Religion, Chulalongkorn University,2014.

[21] Wanida Suwanniphon, Human Capital Potential and Dynamic Capabilities of Thai Software Industry Entrepreneurs to Increase Competitiveness in the ASEAN Economic Community, Verdian E-Journal, Silpakorn University Thai version: vol.10, no.3, pp.1-19, 2017. 